\title{
シンポジウム(7) 顔面神経麻痺の治療と後遺症への対応
}

\author{
司会のことば \\ 村上 信五 \\ 名古屋市立大学 耳鼻咽喉科 \\ 欠畑 誠治 \\ 山形大学 耳鼻咽喉科
}

末梢性顔面神経麻痺は種々の病因で生じるが、Bell 麻痺とRamsay Hunt 症候群の頻度が高く全体の約三分の二を占 め、耳炎性麻痺、外傷性麻痺、腫瘍性麻痺がこれら続く。Bell 麻痺は予後良好な疾患で約 7 割は自然治癒し、適切な治 療を施行すれば $90 \%$ 以上が完治する。一方、Hunt 症候群は予後不良で自然治癒は約 $30 \%$ 、治療にても $70 \%$ 前後しか完 治しない。

Bell 麻痖と Hunt 症候群の治療は、麻痺発症 1 週間以内の急性期治療と 1 週間から 1 力月間の亜急性期治療、それ以 降の慢性期治療に分けることができる。

急性期治療はステロイドや抗ウイルス薬を中心とした薬物治療、亜急性期治療は顔面神経減荷術で、これらの目的は 神経の再生よりはむしろ変性を防止することである。つまり、神経病態学的には髄鞘変性から軸索変性に進行するのを 防ぐことである。そして、これらの治療で神経変性（軸索変性）が90\%（ENoG 10\%）を越えなければ予後は良好で、 顔面の拘縮や病的共同運動も軽微に留まる。しかし、麻痷が重症でかつ早期に適切な治療が施行されなかった場合に は、神経線維は髄鞘変性から軸索変性に移行し、未梢への Waller 变性を来し高度麻痺となる。そして、中枢から表情 筋に神経線維が再生するまで数力月間、麻痺は回復しない。

そして、たとえ麻痺が回復したとしても神経再生の際に生じる線維の sprouting と過誤支配により病的共同運動や拘 縮が生じる。顔面神経麻痺に対するリハビリテーションは麻痺発症 1 カ月以降の慢性期に神経の過誤支配を予防し、病 的共同運動や拘縮を軽減させることを目的として行うものである。しかし、実際に生じた病的共同運動や拘縮はリハビ リテーションでは改善することは困難で、ボトックスの筋注や上眼挙筋などの選択的筋切除術が必要になる。

また、顔面神経麻痺再生の再生は 1 年でほぼ完了し、それ以降の自然回復は期待できない。したがって、麻痺発症 1 年を経過した症例、あるいは外傷や腫瘍で顔面神経が切断された症例には神経の再建や筋移行などの動的再建や眉毛と 吊り上げや face lifting などの静的再建が必要となる。

本シンポジウムでは、顔面神経麻痺の予後診断から急性期の薬物治療、亜急性期の顔面神経減荷術、慢性期のリハビ リ、そして陳旧期の顔面神経再建まで、それぞれのエキスパートにご講演いただきます。1時間半聴講すればあなたも 顔面神経麻痺のエキスパートです。
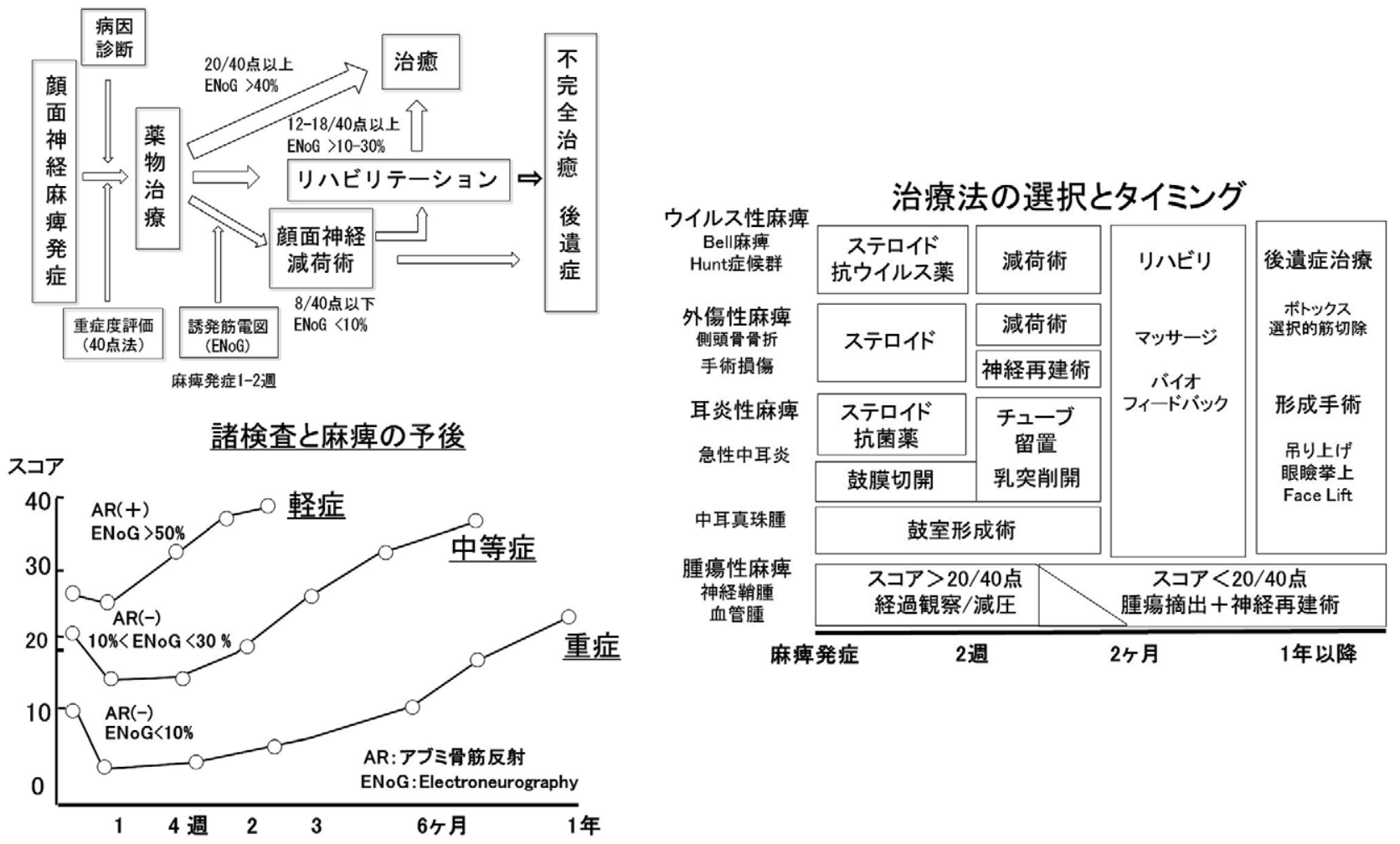


\section{顔面神経麻痺の治療と後遺症への対応＜予後診断＞}

萩森 伸一

大阪医科大学 耳鼻咽喉科・頭頸部外科

顔面神経麻痺患者が最も知りたいことは「治るのか否か」そこて「治るならいつ頃に治るのか」である。麻痺の予 後を正確に推定し、最適な治療を行う責務が耳鼻咽喉科医には求められる。本講演では顔面神経麻痺の予後判定法と注 意点について述べる。

1. 顔面運動評価法（麻痺スコア）

柳原40点法、House-Brackmann 法、Sunnybrook 法が普及している。このうち Sunnybrook 法は後遺症評価に適し、 予後診断に用いられることは少ない。本邦で頻用されるのは柳原40点法である。安静時の左右対称性 1 項目と表情筋運 動 9 項目をそれぞれ 4 点 (ほぼ正常)、2 点 (部分麻痺)、0 点（高度麻痺）の 3 段階で評価し、その合計スコア（40点 満点）を求める。2016年に改定された診断基準では合計10点以下を完全麻痺、12点以上を不全麻痺とする。麻痺の回復 過程で38点以上に回復、かつ中等度以上の後遺症がなければ治癒とする。簡便であり耳鼻科医には最も馴染深いが、病 的共同運動はスコアに反映されない。House-Brackmann 法は顔面運動の包括的評価法で、正常 (grade I) から高度麻 痺（grade VI）の6段階で評価する。病的共同運動など後遺症も grade に反映されるが、部位別評価には適さない。治 癒は grade I または grade II への回復である。いずれの評価法も評価者の主観がある程度反映されることは不可避であ り、したがって結果がばらつきやすい。評価基準の標準化や施設内での調整など、評価者間差異が最小となるよう努め る。

ウイルス性顔面神経麻疩では発症後から麻疩は進行し、1 週間ほどで最も悪い状態となる。村上の検討では柳原40点 法においてこの最悪時のスコアが14点以上であれば絶対的予後良好で、まず治癒に至る。最悪時スコアが12点以下の高 度麻痺例では 3 割が治癒しない一方で、残り 7 割は治癒する。したがって高度麻痺に対する麻痺スコアを用いた早期子 後診断は困難である。他方、高度麻疩であっても発症後 1 カ月の時点において 22 点以上に回復していれば予後は良好で ある。しかし実臨床では予後不良と診断された例には、顔面神経減荷術など追加治療の速やかな実施が望ましく、高度 麻痺例には次に述べる電気生理学的検査を発症早期に行い予後を推定する。

2. 電気生理学的予後診断

いずれも神経軸索変性が完成する発症後10１4日で施行する。

(1) 神経興奮性検査 (Nerve excitability test, NET)

茎乳突孔から側頭骨外に出た顔面神経本幹を乳様突起直下で経皮的に電気刺激し、肉眼で表情筋収縮が確認できる最 小電流量を患側・健側で比較する。(患側電流量) - (健側電流量) が $3.5 \mathrm{~mA}$ 以内では予後良好、3. $5 \mathrm{~mA}$ 以上では予後 不良と判定する。

(2) Electroneurography $(\mathrm{ENoG})$

口輪筋上の皮膚に電極を貼付し NET と同様に顔面神経本幹を電気刺激し、複合筋活動電位（compound muscle action potential, CMAP) を計測する。表情筋収縮間值を観察する NET とは異なり、CMAP が最大となる大電流量で刺 激する。得られた CMAP 電位を以下の計算式に代入して ENoG 值を求める。

ENoG 值 $(\%)=($ 患側 $\mathrm{CMAP}(\mathrm{mV})) /($ 健側 $\mathrm{CMAP}(\mathrm{mV})) \times 100$

ENoG 值は患側の軸索変性を免れた顔面神経線維の割合を表す。ENoG 值が $40 \%$ 以上であれば麻痺は後遺症なく 1 力 月以内に治癒する。 $20 \%$ 以上 $40 \%$ 未満であれば 2 カ月以内に治癒するが、病的共同運動などの後遺症が生ずる可能性が わずかながらある。10\%以上 $20 \%$ 未満であれば 4 カ月以内に治癒するが、後遺症の可能性が高まる。10\%未満であれば 半数は治癒せず、治癒しても 6 力月以上要し、後遺症が高率に生ずる。0％であれば治癒は望めない。

高度麻痺例には NET P ENoGによる予後診断を行い、顔面神経減荷術やリハビリテーションなど追加治療の必要性 を検討する。特に ENoG は顔面神経に生じた軸索変性の割合を定量的に評価できる点で優れ、顔面神経麻痺の診療で は欠くことのできない検査となっている。

参考文献

村上信五：宿題報告2015 ウイルス性顔面神経麻痺一病態と後遺症克服のための新たな治療一。 
ベル麻痺・ハント症候群の薬物療法

演田＼cjkstart昌史

東海大学 医学部 耳鼻咽喉科

1. はじめに

古くよりベル麻疩（特発性顔面神経麻疩）患者に対しては副腎皮質ステロイドが、ラムゼイハント症候群（以下ハン 卜症候群）患者に対してはこれに加え抗ウイルス薬が投与されてきた。しかしながら、ベル麻痺重症例には無疮疹性带 状疮疹（zoster sine herpete；以下 ZSH）が多く、これらの予後が不良であるうえに、初診時にこれを鑑別することが ほほ不可能なことから、われわれはべル麻痺とハント症候群の初期対応をあえて区別せず、麻痺スコアを用いた重症度 別治療を実践している。本口演ではその害際を紹介する。

\section{2. ベル麻痺保存的治療の実際}

図に示すように発症 3 日以内に受診してスコア12点以上の不全麻疩であればプレドニゾロン (PSL) $60 \mathrm{mg}$ 内服とバ ラシクロビル (VCV) 3, $000 \mathrm{mg}$ 内服を併用する。一方で、発症 3 日目以内にすでにスコア10点以下の完全麻疩であれ ば即日入院の上、Stennert法に準じたステロイド大量点滴療法としてハイドロコルチゾン (HC) 1, 000mg（PSL $200 \mathrm{mg}$ とほほ等力価）よりの漸減投与を VCV 3, 000 mg 内服に加えている。初診時に不全麻痺であった場合は発症 3 日 目以後に必ず再診し、完全麻盘への進行を認めた際にはその時点で、同様に入院のうえの大量点滴に切り替えている。

過去 3 年間に 198 人のベル麻瘦患者を本プロトコールに従い診療した結果、完全治癒 I に達した症例が 125 例 (75.3\%)、完全治癒 II が26例 $(15.7 \%) 、$ 不完全治癒が 7 例 $(4.2 \%) 、$ 減荷術を施行したもの（ここでは保存的治療不 成功例として扱う）が8例（4.8\%）であった。全体的な完全治癒率は $91.0 \%$ に達した。初診時からの経過中に不全麻 痺のまま推移した症例では全例が完全治癒となった。

3. ハント症候群完全麻疩に対するステロイド・抗ウイルス薬高用量併用療法

ハント症候群の麻痖予後はベル麻痺に比較して著しく不良である。Murakami らは、PSL 60mg とアシクロビル (ACV) 4, 000 mg の内服あるいは 750mg の点滴を併用した結果、中等症例も含めた治癒率を $53 \%$ と報告した。一方で 稲村らが完全麻痖のみを対象として、PSL 200mg の大量点滴に加えて ACV 750mg の点滴を行ったところ高度麻瘏の治 癒率は $61 \%$ となった。

われわれは図に示すように不全麻痺についてはべル麻痺と同じ内服治療を実践するとともに、初診時すでに完全麻痺 を呈した症例ではべル麻疩同様に HC 1, 000mg を点滴し、これに ACV 1, 500mg（通常量の倍量、 $500 \mathrm{mg} \times 3$ 回／日） を追加した。また不全麻痺から進行が確認された完全麻痺例ではやはりその時点で治療法を変更した。

こうして過去 3 年間にハント症候群60例を治療した結果、完全治癒 I が31例 (56.4\%)、完全治癒IIが15例 (27.3\%)、不完全治癒が 5 例 $(9.1 \%$ )、減荷術施行例が 4 例（7.3\%）となった。完全麻疩症例のみの治癒率は $83.7 \%$ となった。初診時に不全麻瘏であった症例では、そのまま内服により不全麻疩を維持した症例、進行して治療法を点滴 に変更した症例を問わず、全例が治癒していた。

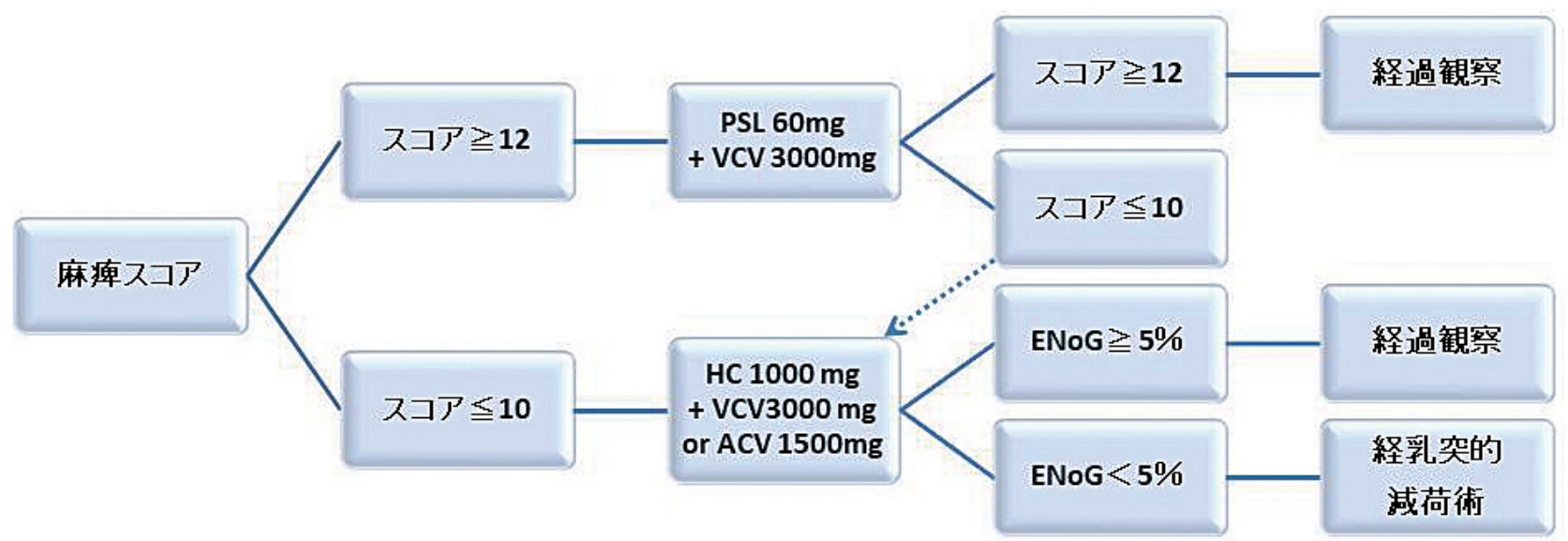




\title{
顔面神経麻痺の手術治療
}

\author{
羽藤 直人 \\ 愛媛大学 医学系研究科 耳鼻咽喉科・頭頸部外科
}

はじめに

顔面神経麻痺に対する耳鼻咽喉科的な手術治療は、顔面神経減荷手術が中心となる。顔面神経減荷手術は、有効性に 関する明確なエビデンスがないため、世界的に減少傾向にある。一方で、顔面神経減荷手術が唯一の有効な手術治療で ある症例は、確実に存在する。また、側頭骨内の顔面神経管に対するアプローチ法は、経乳突法、経中頭蓋窩法あるい は両者の併用と多彩であり、国際標準化されていない。本シンポジウムでは、顔面神経減手術の背景、目的、手術方 法、効果、展望などについて紹介する。

顔面神経減荷手術の現状と問題点

顔面神経減荷手術の対象疾患は Bell 麻疩、Hunt 症候群、側頭骨骨折による外傷性麻疩が代表的である。Bell 麻瘒の 多くと Hunt 症候群は、膝神経節からのウイルス再活性化による神経炎が病因であり、炎症により神経浮腫が生じる と、狭い側頭骨内で神経絞扼が増悪する。その予防が、顔面神経減荷手術の主目的である。Hunt 症候群に関しては、 神経炎が高度で減荷術を行っても転帰不良な症例が多く、欧米では減荷術の効果に否定的な意見が主流だが、本邦では ENoG10\%未満の高度麻疩例には減荷術が適応されている。

一方、Bell 麻痺の HSV 性神経炎の病態に対応した術式として、1999年にGantzらは、手術適応を発症 2 週以内の早 期に限定し、経乳突法と経中頭蓋窩法を併用する全減荷手術を提唱し、良好な成績を示した。また、2001年に Yanagihara らは、発症早期にはステロイド治療を行い、発症 2 週以降の高度麻痺症例に対し、経乳突法による垂直部 から膝神経節までの亜全減荷手術を提唱し、発症後早期であるほど治療成績は良好であるが、麻痺発症 1 力以上経過 しても、ある程度の意義があることを示した。これは、HSV が再活性化する膝神経節より末梢の減荷でも、側頭骨内 の骨間内で生じた炎症、浮腫、絞扼の悪循環を改善すれば、神経再生環境の向上につながる症例が存在することを示し たと言える。Gantz 論文と Yanagihara 論文の発表以降、Bell 麻痺に対しては、欧米では 2 週以内の経中頭蓋窩法と経 乳突法を併用した全減荷が主流となり、本邦では発症 2 週以降の症例に対して経乳突法の減荷手術が行われる、ダブ ル・スタンダードの時代が続いている。

側頭骨骨折による外傷性麻瘴に対しては、世界共通で即発性の高度麻痺へ減荷術が適応されている。手術の目的は、 骨折に伴う物理的な神経圧迫や牽引を解除することで、神経生理学的に合目的である。術式は骨折部位や病態により、 経中頭蓋窩法、経乳突法、場合によっては経迷路法が選択される。減荷術の至適時期として、演者は発症 2 週以内、遅 くとも2 月 月以内提唱している。合併症や全身状態が許せば、発症早期であるほど治療成績は良いが、出血し易く手 術の難易度は上がる。

\section{顔面神経減荷手術の展望}

このように、顔面神経減荷手術の課題は多いが、発症後 2 週以上を経過した症例に対する治療成績の向上が、重要な 課題と考える。そのためには、(1) 神経絞扼の解除、(2) 神経血流とリンパ流の回復、(3) 脳幹の顔面神経ニューロン変 性前の再生完了などの条件を満たさなければならない。現在われわれは、減荷手術時に顔面神経へ徐放化栄養因子を投 与する再生治療を行っている。(1) 神経再生を促進、(2) 発症 2 週以降経過していても可能、(3) 低侵襲な手術手技、(4) 合併症の軽減をコンセプトとしており、これまでの成績は良好で、普遍的な治療となる可能性がある。

さらに、除法化栄養因子を経鼓膜的に鼓室内に投与する、低侵襲顔面神経再生療法を基礎研究として行っている。本 治療は発症早期からステロイドの全身投与に追加可能であり、耳鼻科医であれば外来にて簡便に実施できるため、より 汎用性が高い。

\section{まとめ}

顔面神経減荷手術は、保険収載された治療法であるが、その意義や方法に国際的なコンセンサスがまだ得られていな い。今後の前向きランダム化比較試験による有効性検証が必須である。また、再生医療を融合させた新たな顔面神経再 生手術としての展開が期待される。 
リハビリテーション

東 貴弘 徳島大学 医学部 耳鼻咽喉科

末梢性顔面神経麻痺は比較的予後良好な疾患であるが、適切な初期治療を受けたにもかかわらず高度な神経障害を来 した症例では後遺症が発症する。顔面神経麻痺後の後遺症には、病的共同運動、顔面拘縮、顔面㽷攣、鰐の涙、鐙骨筋 性耳鳴などがあるが、病的共同運動が最も頻度が高く不快な後遺症である。末梢性顔面神経麻痺後の病的共同運動は、 障害をうけた顔面神経が迷入再生し、元々支配していた表情筋と異なる表情筋を支配することで起こる顔面の不随意運 動である。代表的な病的共同運動には、口運動時の不随意な閉瞼や瞬目時の不随意な口角偏倚などがある。中でも口運 動時の不随意な閉憸の病的共同運動が最も不快で、会話や食事の際に眼輪筋が不随意に収縮するために瞼裂が狭小化 し、苦しむ患者が多い。

病的共同運動はいったん発症すれば治療が困難である。われわれは、最も不快な口運動時の不随意な閉瞼を予防する リハビリテーションであるミラーバイオフィードバック療法を開発した。また発症した病的共同運動を治療することが できるボッリヌス毒素・ミラーバイオフィードバック併用療法も、新たに開発した。

ミラーバイオフィードバック療法とは、鏡を見ながら表情筋の動きをコントロールし、病的共同運動を抑制するリハ ビリテーションである。具体的には、瞼裂の対称性を保つように意識しながらウーと唇を尖らせる、イーと歯を見せ る、プーとほほを膨らませる口運動を行わせる。1 日30分、毎日自宅で行うように指導する。必ず鏡を見ながら行うこ と、ゆっくりと優しく口運動を行うこと、筋力強化ではなく左右の瞼裂の対称性を保つことを意識することが重要であ る。

われわれは、ENoG 值が 0 \%の高度な神経障害を来した末梢性顔面神経麻痺患者を対象に、表情筋の動きが回復を始 めた時期よりミラーバイオフィードバック療法を開始し、顔面神経麻痺発症 1 年後の病的共同運動の程度を瞼裂比で評 価したところ、予防を行わなかった患者群と比較して瞼裂比は有意に高く、病的共同運動の発症が予防できることを明 らかにした。またわれわれの検討から、ENoG 值が46.5\%以下の患者では病的共同運動が発症する可能性が高く、積極 的にミラーバイオフィードバック療法による予防が必要である。

一方、発症した病的共同運動は、ミラーバイオフィードバック療法のみでは治療困難である。すでに存在する病的共 同運動がミラーバイオフィードバック療法を阻害するからである。また、ボッリヌス毒素は一時的に病的共同運動を改 善させことができるが、効果は $3 \sim 4$ カ月で消失するため、反復投与が必要である。そこでわれわれは、ボツリ又ス毒 素・ミラーバイオフィードバック併用療法を開発した。具体的には、最初に一回だけボッリヌス毒素を病的共同運動が 発症している眼輪筋に局所投与し、ミラーバイオフィードバック療法を阻害していた病的共同運動を一時的に軽快させ てからミラーバイオフィードバック療法を開始し、継続する治療方法である。

われわれの検討では、高度な口運動時の不随意な閉瞼の病的共同運動を発症した末梢性顔面神経麻瘏後の患者に対し て、ボッリヌス毒素・ミラーバイオフィードバック併用療法を行ったところ、治療開始後10カ月の瞼裂比は有意に上昇 した。このことから、発症すれば治療困難とされた病的共同運動を、ボッリヌス毒素・ミラーバイオフィードバック併 用療法で治療できることが明らかになった。

参考文献

Nakamura K, et al : Otolaryngol Head Neck Surg 2003 ; 128 : 539-543.

Azuma T, et al : Otolaryngol Head Neck Surg 2012 ; 146 : 40-45.

Azuma T, et al : Auris Nasus Larynx 2018 ; 45 : 728-731. 


\title{
顔面神経麻痺の形成外科的治療
}

\author{
朝戸 裕貴 \\ 獨協医科大学 医学部 形成外科
}

顔面神経麻痺の治療においては形成外科的手技を必要とする場合がある。日本顔面神経学会では多くの形成外科医が 主に顔面神経再建や後遺症の形成外科的治療について例年発表している。これらの発表を紹介しながら形成外科的治療 の概略について述べたい。

耳下腺腫瘍における神経合併切除の際など、即時再建が必要となる場合には神経移植が行われるが、それぞれの分枝 について端々縫合を行うのではなく、端側縫合を利用してループ型神経移植を行う方法が報告され（垣淵ら）、顔面神 経領域における端側縫合の有用性が議論になっている。また端側縫合による神経付加を行うことで、舌下神経そのほか の神経を用いて顔面神経麻痺患者に対する動的神経再建を行う方法が近年多く発表されてきている（山本ら、橋川ら、 など)。

麻疩による閉憸不全に対しては古くょり行われている側頭筋移行術以外に、20年ほど前は gold plateによる lid loading 法が広く用いられてきたが、この gold plate は医療機器承認を得られなかったため、それに代わる方法として levator lengthening 法（林ら）が注目されている。

後遺症の異常共同運動や顔面拘縮による開噞障害や口角のひきつれに対しても、拘縮を起こした筋の部分離断や部分 切除などの形成外科的手術治療が行われている。

陳旧性麻㿁となった症例に対して、40年以上前に発表された神経血管付き筋肉移植術（波利井ら）は、その後大きく 発展して現在では一期的遊離広背筋移植を中心とした方法が主として行われている。この方法は神経血管付きの広背筋 を顔面に移植し、対側顔面神経と神経縫合、患側顔面動静脈と血管吻合を行うことで、「笑い」の表情をつくる手術で ある。筆者も数多く行ってきているが、安定した結果が得られている。近年咬筋神経からの神経付加を利用しょうとい う発表がみられ（渡辺ら）現在注目されているところである。

顔面神経麻痺の形成外科的治療は多岐にわたっており、今後のさらなる展開が期待されている分野であると考える。 